\title{
Scour Features at Wood Bundles
}

\author{
Simone Pagliara ${ }^{1}\left[\right.$, Deep Roy ${ }^{2} \mathbb{C}$ and Michele Palermo ${ }^{2, *} \mathbb{(}$ \\ 1 Laboratory of Hydraulics, Hydrology and Glaciology (VAW), ETH Zurich, 8049 Zurich, Switzerland; \\ pagliara@vaw.baug.ethz.ch \\ 2 DESTEC-Department of Energy, Systems, Territory and Construction Engineering, University of Pisa, \\ 56122 Pisa, Italy; d.roy1@studenti.unipi.it \\ * Correspondence: michele.palermo@ing.unipi.it; Tel.: +39-050-2217929
}

\section{check for}

updates

Citation: Pagliara, S.; Roy, D.; Palermo, M. Scour Features at Wood Bundles. Water 2021, 13, 2118.

https://doi.org/10.3390/w13152118

Academic Editor:

Miguel Ortega-Sánchez

Received: 10 July 2021

Accepted: 28 July 2021

Published: 31 July 2021

Publisher's Note: MDPI stays neutral with regard to jurisdictional claims in published maps and institutional affiliations.

Copyright: (c) 2021 by the authors. Licensee MDPI, Basel, Switzerland. This article is an open access article distributed under the terms and conditions of the Creative Commons Attribution (CC BY) license (https:// creativecommons.org/licenses/by/ $4.0 /)$.

\begin{abstract}
Structures like blunt-nosed chevrons, log deflectors and double-winged log frames help in modifying the flow regime in the channel by concentrating the flow and increasing navigability. Moreover, they create scour pools in the downstream stilling basin, which can be used either as fish refuge or as an in-stream storage site for previously dredged material. In this respect, the use of wood debris in the channel in the form of wood bundles has gained attention for the ability of these structures to integrate into the surrounding fluvial habitat and to divert the flow partially towards the central part of the channel when placed in curves. Considering the absence of studies dealing with wood bundles as a restoration structure, the aim of this paper is to analyse the scour mechanism and equilibrium scour morphology of wood bundles in straight and curved channels. In doing so, a wide range of hydraulic conditions, structure positions and configurations were tested. Thereafter, dimensional analysis was carried out to derive useful empirical relationships to predict the maximum scour depth and length as well as the maximum dune height based on a novel, equivalent Froude number, which accounts for the effects of channel curvature and structure position. Moreover, the various resulting scour morphology types were classified, and conditions of their existence were determined depending on the abovementioned Froude number and other key hydraulic parameters.
\end{abstract}

Keywords: curved channel; equilibrium morphology; scour; wood bundles

\section{Introduction}

River systems are a crucial component of the fresh water resources of the world. Due to overwhelming anthropogenic activity and climate change, most of the world's rivers have undergone degradation in terms of sediment-carrying potential and channel stability. The restoration of such rivers can be done either passively by promoting proper land use and irrigation [1] or more actively by installing low-head river restoration structures to enhance grade control and aquatic habitat [2]. Recently, the emphasis of hydraulic engineers has been on the use of eco-friendly structures (such as cross weirs, log frames and chevrons), which can modify the sediment-carrying potential of the rivers and create low- velocity localised scour zones to be used by fish and other organisms as resting spots in their migration path. In curved channels, the flow is asymmetric in nature because of the centrifugal force acting on it, and this increases the scour along the outer channel bank. In such a situation, some of these structures (such as J-Hook vanes) can be placed in the vicinity of the outer bank to divert the high flow gradients towards the centre of the channel and thereby protect the outer bank from failure.

Several studies can be found in the literature addressing in-stream scour phenomena. Among early research, Refs. [3,4] made important contributions in analysing local scour processes. Following this, various studies [5-8] carried out investigation of scour phenomena corresponding to specific hydraulic structures. The authors of $[9,10]$ compiled the various empirical equations used to quantify scour geometry features and showed their advantages and limitations. In addition, efforts were made by researchers to model the 
scour mechanism using a semi- or fully analytical approach like Newton's second law or the phenomenological theory of turbulence [11-13].

With regard to low-head river restoration structures, progress was made in characterizing the scour in the vicinity of specific structures. The authors of [14] provided an important study regarding the scour pattern due to $\mathrm{W}$-weirs located at the meandering bend of a channel, whereas [15] analysed the effectiveness of vanes to restrict erosion of river banks in curved channels. In [16], the authors investigated the local 3-D scour features occurring in correspondence with $\mathrm{W}$-weirs and cross-vanes in straight channels. Following this, the authors of $[17,18]$ estimated the major scour parameters due to J-Hook vanes in straight and curved channels, respectively, under clear water conditions. Moreover, the morphological features of both unprotected and protected stilling basins for block ramps in curved channels were studied by $[19,20]$, respectively. More recently, experimental tests were conducted by the authors of [21] to classify the equilibrium scour morphology and develop empirical equations to predict the maximum scour depth due to blunt-nosed chevrons in straight channels.

Among wood-made structures, the engineering applicability and hydraulic behaviour of log vanes, log deflectors and double-winged log frames were studied by [22-24], respectively. These structures are used to enhance bank protection and increase the biodiversity in the channel by promoting pisciculture and growth of other aquatic organisms. Apart from this, the presence of large woody debris (diameter $>0.1 \mathrm{~m}$ and length $>2 \mathrm{~m}$ ) results in significant flow alterations and an increase in the percentage of organic material in the channel as well as the generation of nesting regions for reptiles and birds and enhanced fish migration [25]. A detailed review of the existing studies on such in-stream wood debris was done by the author of [26], who concluded that the removal of debris from the channel can lead to a decrease in the roughness and friction factor, thereby increasing the overall conveyance (see also [27]). However, an essential quantity of debris is required to be maintained in the channel to create and sustain hydraulic diversity and desirable fluvial habitat.

Based on the above literature survey, it can be said that, to the best of the authors' knowledge, there are no studies dealing with the analysis of the various equilibrium scour morphology types and major parameters governing the scour in the vicinity of large woody debris (wood bundles) in both straight and curved channels. Therefore, in this paper, we undertook an extensive experimental campaign to study the scour characteristics at wood bundles under a variety of hydraulic conditions and structure positions. The number of structures in a series arrangement was also varied. Dimensional analysis allowed us to deduce a novel, equivalent densimetric Froude number, which served as the basis for explaining and quantifying the scour mechanism. Crucial geometric features of the localised scour hole and dune, like the maximum scour depth and length and the maximum dune height, were predicted by deriving empirical equations having good accuracy.

The equilibrium scour morphological features are classified, and the usefulness of such structures in creating eco-friendly scour pools towards the central part of the channel in river bends is highlighted.

\section{Materials and Methods}

Tests on wood bundles were carried out at the hydraulics laboratory of the University of Pisa in a channel composed of an initial straight portion followed by a curved portion. The straight portion was $12 \mathrm{~m}$ long, $0.5 \mathrm{~m}$ wide and $0.5 \mathrm{~m}$ deep. The curved portion of the channel was $3.7 \mathrm{~m}$ long, $0.5 \mathrm{~m}$ wide and $0.5 \mathrm{~m}$ deep and was characterised by a radius of curvature $(R)$ equal to $2 \mathrm{~m}$. In the straight portion, tests were carried out by placing an isolated wood bundle in the vicinity of the channel bank at a distance of $d$ from the channel entrance, where $d / B=16$ (Figure 1a). Moreover, the transversal structure position was defined by $b / B=0.15$. $B$ and $b$ denote the channel width and transversal distance of centre of mass of the wood bundle structure from the inner channel bank, respectively. 


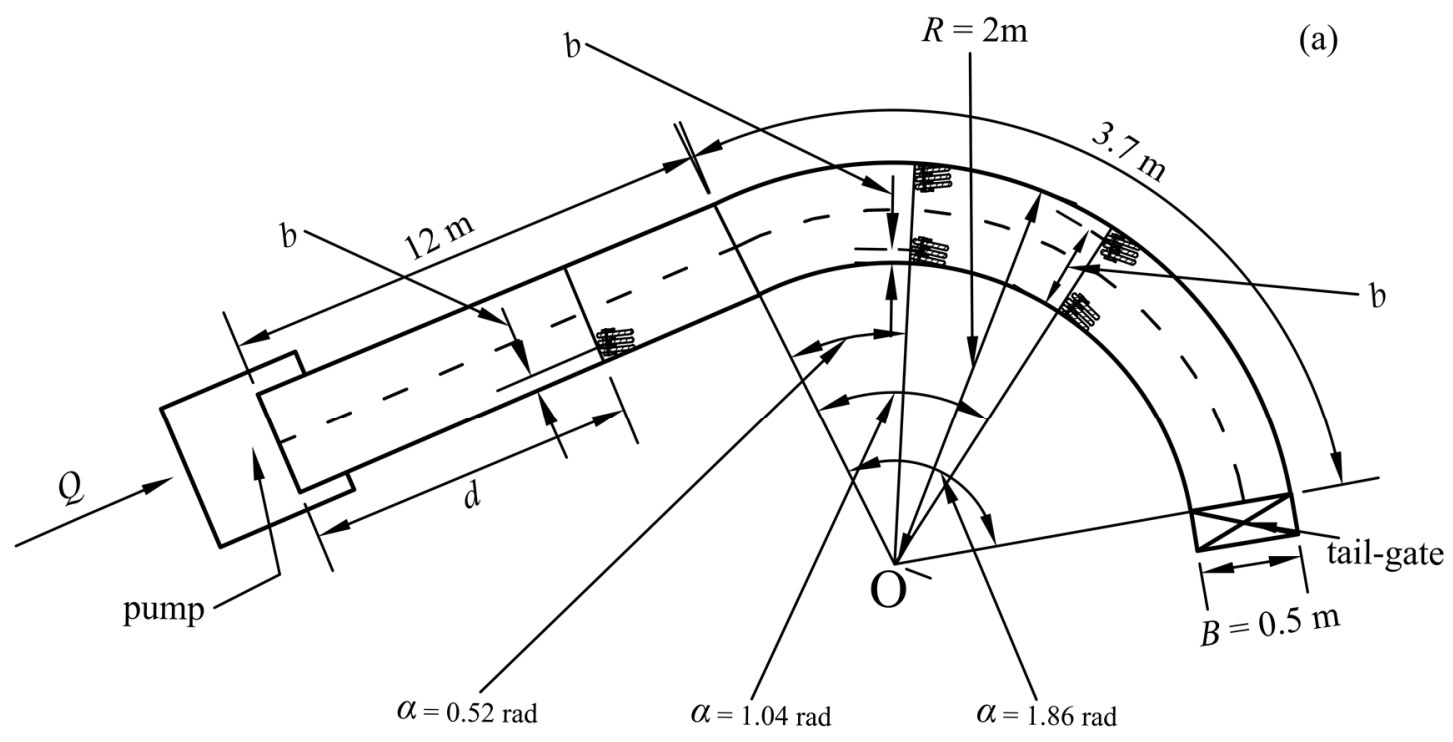

wood bundle
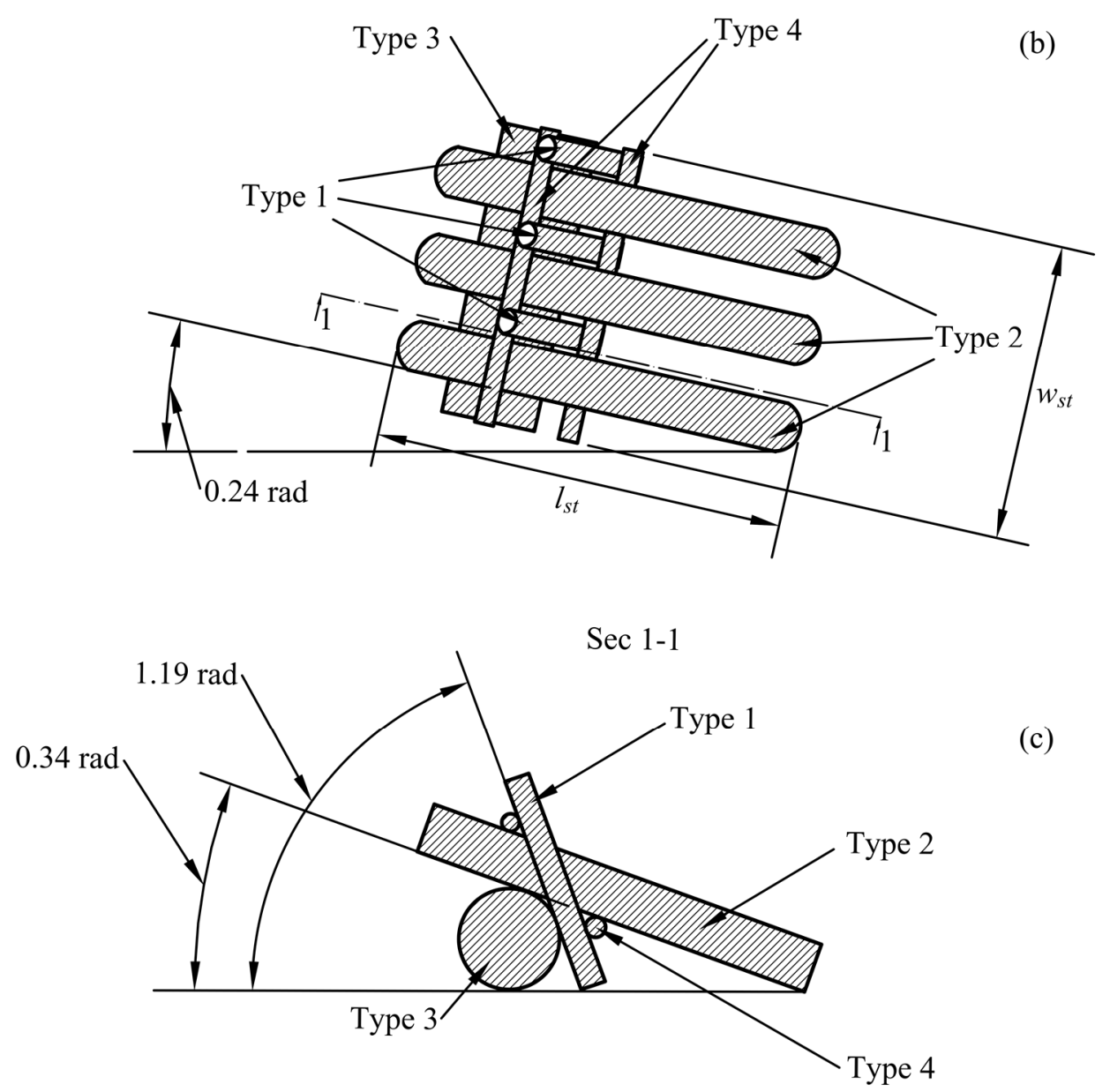

Figure 1. (a) Experimental channel showing longitudinal and transversal wood bundle positions in straight and curved channel. $(\mathbf{b}, \mathbf{c})$ Plan and side views of the individual wood bundle structure adopted in the study.

Thereafter, the same tests were repeated with structure series containing two or three structures, with $n$ denoting the number of structures in a series arrangement. Following 
this, similar tests were conducted by placing an isolated wood bundle in the curved portion of the channel for each of the two angular positions of the structure in the curve $(\alpha)$, defined as $\alpha=0.52 \mathrm{rad}$ and $1.04 \mathrm{rad}$ (Figure 1a). Likewise, two different transversal positions were also tested, i.e., in the inner bank vicinity, defined by $b / B=0.15$, and in the outer bank vicinity, defined by $b / B=0.85$ (in curved channels, $b$ denotes the transversal distance of the centre of mass of the wood bundle from the inner bank). In addition, for curved channels, tests with multiple wood bundles were carried out with identical hydraulic conditions and structure positions as those for an isolated structure. The positions of the wood bundle shown in Figure 1a correspond to the five different transversal and longitudinal positions of the structure tested in the current study and denote the position of the first wood bundle in the case of the series arrangement.

As shown in Figure 1b,c the wood bundle was constructed from four different types of cylindrical logs tied together with metallic strings and having the following characteristics: Type 1 (length $=0.09 \mathrm{~m}$, diameter $=0.01 \mathrm{~m}$ and angle with horizontal $=1.19 \mathrm{rad}$ ), Type 2 (length $=0.16 \mathrm{~m}$, diameter $=0.02 \mathrm{~m}$ and angle with horizontal $=0.34 \mathrm{rad}$ ), Type 3 (length $=0.145 \mathrm{~m}$, diameter $=0.04 \mathrm{~m}$ and horizontal) and Type 4 (length $=0.145 \mathrm{~m}$, diameter $=0.008 \mathrm{~m}$ and horizontal). Three Type 1 and Type 2 logs were stacked in the longitudinal direction and locked together using a single Type 3 and two Type 4 logs placed transversally. $l_{s t}$ and $w_{s t}$ denote the length and width of the composite structure, respectively, and are defined by $l_{s t} / B=0.32$ and $w_{s t} / B=0.29$. The structure was inclined at an angle of 0.24 rad with the channel bank in all cases. The type of wood used for these structures may vary according to in situ availability. However, the selected wood should not be subjected to a rapid degradation in wet environments. In terms of scour features, the specific roughness of the wood is reasonably negligible, as manufactured pieces of wood are combined.

Figure 2a-d show the plan and cross-sectional views of a wood bundle series arrangement consisting of three structures along with important hydraulic and scour parameters in straight and curved channels. The structural arrangement and other parameters for a single wood bundle or wood bundle series with two structures are similar. In all test conditions, the structures were placed on a stone support to prevent sinking during the experiment. Moreover, $z_{m-1}, z_{m-2}$ and $z_{m-3}$ denote the maximum scour depth occurring in the upstream vicinity of the first, second and third structure in the wood bundle series, respectively. $z_{m b}$ is the maximum scour depth occurring in the vicinity of the outer bank when the structure/structure series is located at the inner bank. Likewise, $z_{M-1}, z_{M-2}$ and $z_{M-3}$ are the maximum heights of dune downstream of the first, second and third structure, respectively. On the other hand, $l_{m-1}, l_{m-2}$ and $l_{m-3}$ are the maximum scour lengths occurring in the vicinity of the first, second and third structure in the series, respectively, and $l_{M}$ denotes the overall maximum dune length. Notably, in curved channels, the various scour lengths are measured along the curved abscissa. The height of the structure is given by $h_{s t} . Q$ and $h_{t w}$ are the flow discharge and tailwater levels, respectively. $\Delta y$ is the difference in the water level upstream and downstream of the structure. The distance between two consecutive wood bundles in a series arrangement is given by $s$. For straight channels, $s / B=0.26$ and 0.52 were tested, whereas for all tests in curved channels, $s / B=0.26$. 


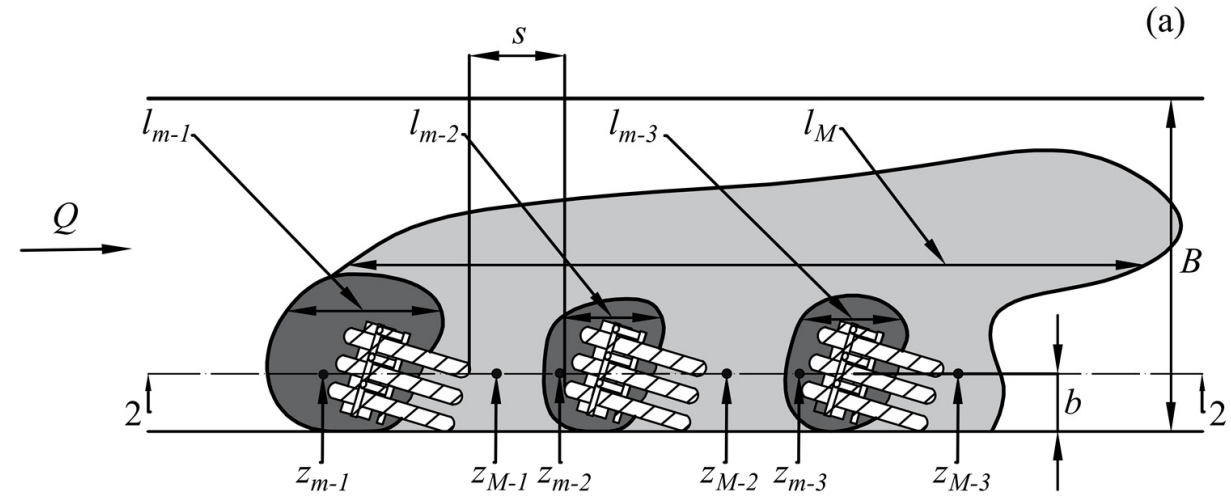

Sec 2-2

(b)
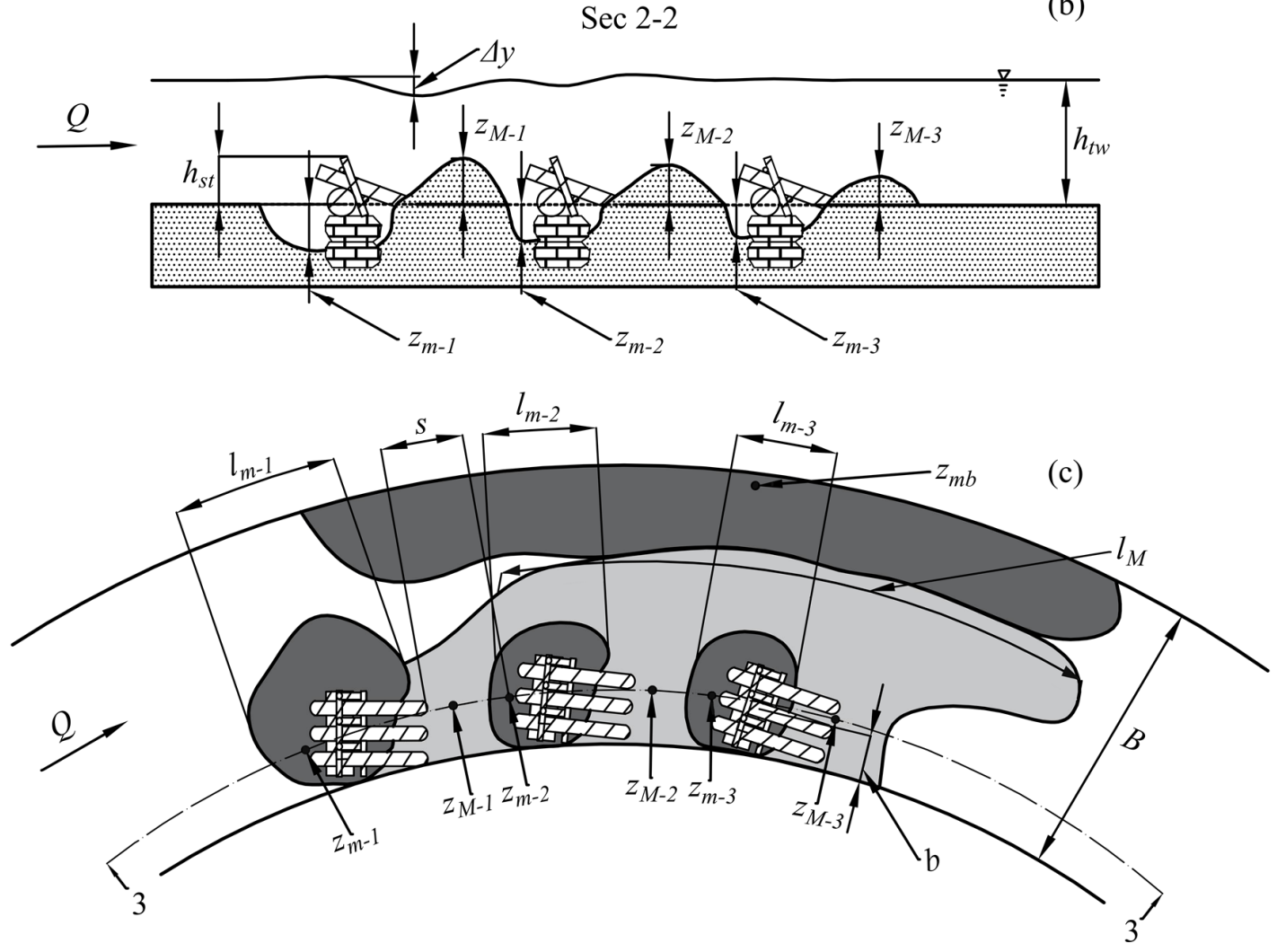

Sec 3-3

(d)

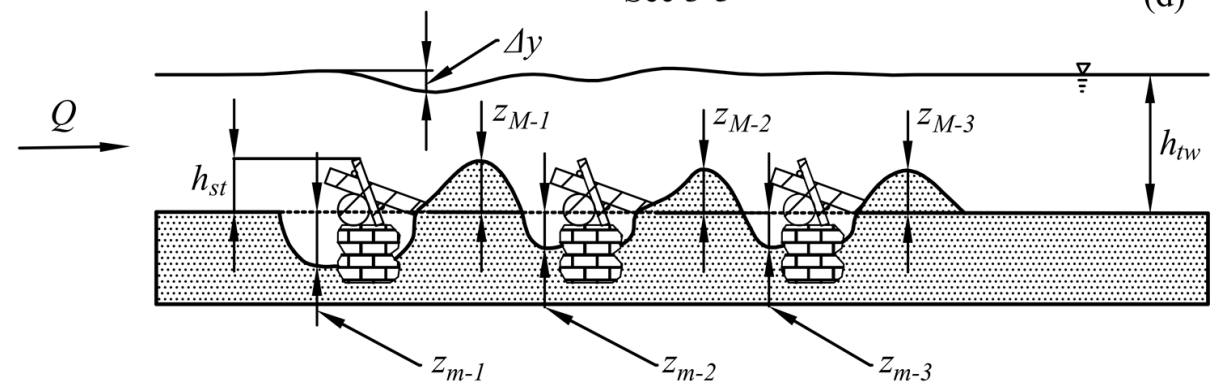

7 wood bundle $\square$ scour $\square$ dune

Figure 2. (a) Plan and (b) cross-sectional views of the wood bundle structure series along with important hydraulic and scour parameters in the case of straight channels; (c) plan and (d) cross-sectional views of the wood bundle structure series in the case of curved channels. 
All the tests were conducted with uniform bed material, characterized by the following granulometric properties: median diameter $d_{50}=1 \mathrm{~mm}$, sediment non-uniformity parameter $\sigma=\left(d_{84} / d_{16}\right)^{0.5}=1.15$, where $d_{x x}$ signifies the sediment diameter size for which $x x \%$ of material is finer. The bed material and water density are denoted by $\rho_{s}$ and $\rho$, respectively. In the present study, $\rho_{s}=2467 \mathrm{~kg} / \mathrm{m}^{3}$ and $\rho=1000 \mathrm{~kg} / \mathrm{m}^{3}$. The bed material was chosen in accordance with the criterion $d_{50}>0.8 \mathrm{~mm}$ to avoid viscous and sediment cohesive effects [28]. Figure 3a,b show the equilibrium scour morphology due to wood bundles in curved and straight channels, respectively. Figure $3 \mathrm{c}$ shows the curve of the channel in which a series of three structures is located. The experimental conditions and results are listed in Table 1.
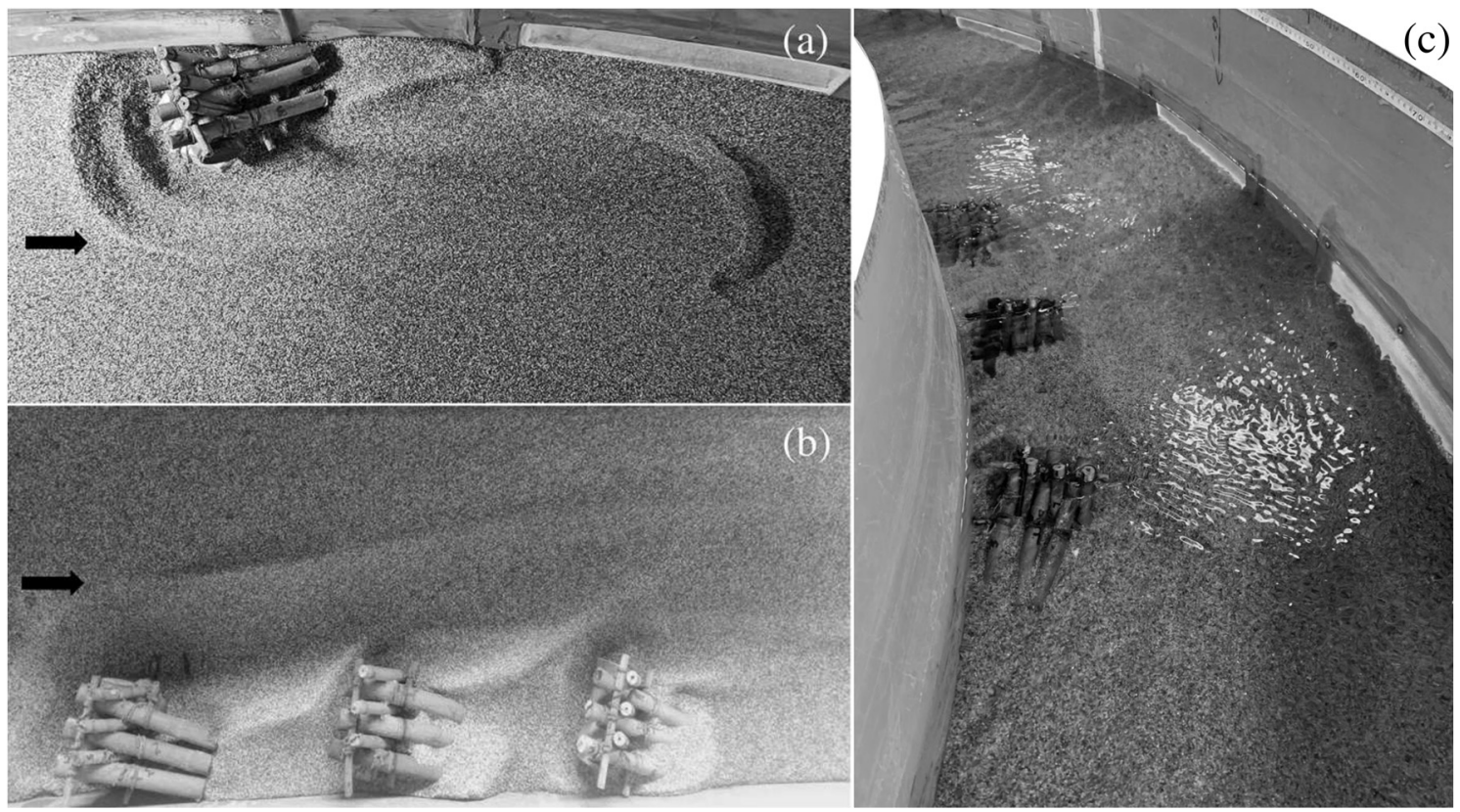

Figure 3. Equilibrium scour morphology in (a) curved and (b) straight channels. The black arrow shows the flow direction. (c) Curve of the channel, including a series of three structures during a test. The direction of the flow is from top to bottom.

Table 1. Summary of experimental conditions and results.

\begin{tabular}{|c|c|c|c|c|c|c|c|c|c|c|c|c|}
\hline $\begin{array}{l}\text { Test } \\
\text { No. }\end{array}$ & $\underset{\left(\mathrm{m}^{3} / \mathrm{s}\right)}{Q}$ & $\begin{array}{c}n \\
(-)\end{array}$ & $\begin{array}{c}b / B \\
(-)\end{array}$ & $\begin{array}{c}(B-b) / R \\
(-)\end{array}$ & $\begin{array}{c}s / B \\
(-)\end{array}$ & $\begin{array}{c}\alpha \\
\text { (rad) }\end{array}$ & $\begin{array}{l}h_{s t} \\
(\mathrm{~m})\end{array}$ & $\begin{array}{l}h_{t w} \\
(\mathrm{~m})\end{array}$ & $\begin{array}{l}z_{m} \\
(\mathrm{~m})\end{array}$ & $\begin{array}{l}l_{m} \\
(\mathrm{~m})\end{array}$ & $\begin{array}{l}z_{M} \\
(\mathrm{~m})\end{array}$ & $\begin{array}{l}z_{m b} \\
(\mathrm{~m})\end{array}$ \\
\hline 1 & 0.005 & 1 & 0.15 & 0 & - & - & 0.073 & 0.034 & 0.058 & 0.400 & 0.024 & - \\
\hline 2 & 0.005 & 1 & 0.15 & 0 & - & - & 0.073 & 0.039 & 0.040 & 0.200 & 0.029 & - \\
\hline 3 & 0.008 & 1 & 0.15 & 0 & - & - & 0.073 & 0.042 & 0.072 & 0.450 & 0.022 & - \\
\hline 4 & 0.008 & 1 & 0.15 & 0 & - & - & 0.073 & 0.060 & 0.036 & 0.240 & 0.019 & - \\
\hline 5 & 0.011 & 1 & 0.15 & 0 & - & - & 0.073 & 0.078 & 0.030 & 0.220 & 0.018 & - \\
\hline 6 & 0.011 & 1 & 0.15 & 0 & - & - & 0.073 & 0.063 & 0.066 & 0.450 & 0.023 & - \\
\hline 7 & 0.011 & 1 & 0.15 & 0 & - & - & 0.073 & 0.071 & 0.048 & 0.350 & 0.024 & - \\
\hline 8 & 0.005 & 2 & 0.15 & 0 & 0.26 & - & 0.079 & 0.041 & 0.027 & 0.270 & 0.018 & - \\
\hline 9 & 0.011 & 2 & 0.15 & 0 & 0.26 & - & 0.079 & 0.073 & 0.046 & 0.280 & 0.026 & - \\
\hline 10 & 0.011 & 2 & 0.15 & 0 & 0.26 & - & 0.079 & 0.063 & 0.081 & 0.400 & 0.027 & - \\
\hline 11 & 0.005 & 2 & 0.15 & 0 & 0.26 & - & 0.079 & 0.033 & 0.058 & 0.380 & 0.027 & - \\
\hline 12 & 0.011 & 2 & 0.15 & 0 & 0.52 & - & 0.079 & 0.072 & 0.028 & 0.300 & 0.016 & - \\
\hline 13 & 0.011 & 2 & 0.15 & 0 & 0.52 & - & 0.079 & 0.065 & 0.044 & 0.340 & 0.026 & - \\
\hline 14 & 0.005 & 2 & 0.15 & 0 & 0.52 & - & 0.073 & 0.038 & 0.047 & 0.240 & 0.026 & - \\
\hline 15 & 0.005 & 2 & 0.15 & 0 & 0.52 & - & 0.073 & 0.034 & 0.059 & 0.310 & 0.027 & - \\
\hline 16 & 0.011 & 3 & 0.15 & 0 & 0.26 & - & 0.079 & 0.072 & 0.070 & 0.360 & 0.026 & - \\
\hline 17 & 0.005 & 3 & 0.15 & 0 & 0.52 & - & 0.079 & 0.036 & 0.054 & 0.330 & 0.028 & - \\
\hline 18 & 0.013 & 3 & 0.15 & 0 & 0.26 & - & 0.073 & 0.088 & 0.053 & 0.350 & 0.030 & - \\
\hline 19 & 0.011 & 3 & 0.15 & 0 & 0.52 & - & 0.079 & 0.070 & 0.063 & 0.310 & 0.023 & - \\
\hline
\end{tabular}


Table 1. Cont.

\begin{tabular}{|c|c|c|c|c|c|c|c|c|c|c|c|c|}
\hline $\begin{array}{l}\text { Test } \\
\text { No. }\end{array}$ & $\begin{array}{c}Q \\
\left(\mathrm{~m}^{3} / \mathrm{s}\right)\end{array}$ & $\begin{array}{c}n \\
(-)\end{array}$ & $\begin{array}{c}b / B \\
(-)\end{array}$ & $\begin{array}{c}(B-b) / R \\
(-)\end{array}$ & $\begin{array}{c}s / B \\
(-)\end{array}$ & $\begin{array}{c}\alpha \\
(\mathrm{rad})\end{array}$ & $\begin{array}{l}h_{s t} \\
(\mathrm{~m})\end{array}$ & $\begin{array}{l}h_{t w} \\
(\mathrm{~m})\end{array}$ & $\begin{array}{l}z_{m} \\
(\mathrm{~m})\end{array}$ & $\begin{array}{l}l_{m} \\
(\mathrm{~m})\end{array}$ & $\begin{array}{l}z_{M} \\
(\mathrm{~m})\end{array}$ & $\begin{array}{l}z_{m b} \\
(\mathrm{~m})\end{array}$ \\
\hline 20 & 0.011 & 1 & 0.15 & 0.213 & - & 0.52 & 0.073 & 0.071 & 0.072 & 0.370 & 0.045 & 0.033 \\
\hline 21 & 0.005 & 1 & 0.15 & 0.213 & - & 0.52 & 0.073 & 0.041 & 0.058 & 0.320 & 0.024 & 0.002 \\
\hline 22 & 0.008 & 1 & 0.15 & 0.213 & - & 0.52 & 0.073 & 0.045 & 0.069 & 0.350 & 0.034 & 0.069 \\
\hline 23 & 0.008 & 1 & 0.15 & 0.213 & - & 0.52 & 0.073 & 0.061 & 0.045 & 0.280 & 0.036 & 0.003 \\
\hline 24 & 0.011 & 1 & 0.15 & 0.213 & - & 0.52 & 0.073 & 0.066 & 0.083 & 0.400 & 0.048 & 0.083 \\
\hline 25 & 0.008 & 2 & 0.15 & 0.213 & 0.26 & 0.52 & 0.079 & 0.058 & 0.055 & 0.320 & 0.029 & 0.012 \\
\hline 26 & 0.011 & 2 & 0.15 & 0.213 & 0.26 & 0.52 & 0.079 & 0.070 & 0.070 & 0.370 & 0.036 & 0.061 \\
\hline 27 & 0.005 & 3 & 0.15 & 0.213 & 0.26 & 0.52 & 0.079 & 0.039 & 0.045 & 0.300 & 0.021 & 0.011 \\
\hline 28 & 0.008 & 3 & 0.15 & 0.213 & 0.26 & 0.52 & 0.079 & 0.060 & 0.049 & 0.280 & 0.024 & 0.014 \\
\hline 29 & 0.011 & 3 & 0.15 & 0.213 & 0.26 & 0.52 & 0.079 & 0.070 & 0.073 & 0.360 & 0.028 & 0.073 \\
\hline 30 & 0.005 & 1 & 0.15 & 0.213 & - & 1.04 & 0.073 & 0.040 & 0.036 & 0.240 & 0.017 & 0.005 \\
\hline 31 & 0.005 & 1 & 0.15 & 0.213 & - & 1.04 & 0.073 & 0.037 & 0.053 & 0.320 & 0.026 & 0.002 \\
\hline 32 & 0.008 & 1 & 0.15 & 0.213 & - & 1.04 & 0.073 & 0.048 & 0.071 & 0.440 & 0.036 & 0.035 \\
\hline 33 & 0.008 & 1 & 0.15 & 0.213 & - & 1.04 & 0.073 & 0.057 & 0.042 & 0.290 & 0.029 & 0.007 \\
\hline 34 & 0.011 & 1 & 0.15 & 0.213 & - & 1.04 & 0.073 & 0.065 & 0.058 & 0.380 & 0.037 & 0.035 \\
\hline 35 & 0.011 & 1 & 0.15 & 0.213 & - & 1.04 & 0.073 & 0.072 & 0.071 & 0.440 & 0.043 & 0.018 \\
\hline 36 & 0.005 & 2 & 0.15 & 0.213 & 0.26 & 1.04 & 0.079 & 0.038 & 0.033 & 0.210 & 0.014 & 0.006 \\
\hline 37 & 0.008 & 2 & 0.15 & 0.213 & 0.26 & 1.04 & 0.079 & 0.060 & 0.044 & 0.320 & 0.029 & 0.013 \\
\hline 38 & 0.011 & 2 & 0.15 & 0.213 & 0.26 & 1.04 & 0.079 & 0.070 & 0.059 & 0.370 & 0.041 & 0.039 \\
\hline 39 & 0.005 & 3 & 0.15 & 0.213 & 0.26 & 1.04 & 0.079 & 0.038 & 0.040 & 0.280 & 0.020 & 0.013 \\
\hline 40 & 0.008 & 3 & 0.15 & 0.213 & 0.26 & 1.04 & 0.079 & 0.058 & 0.050 & 0.340 & 0.033 & 0.027 \\
\hline 41 & 0.011 & 3 & 0.15 & 0.213 & 0.26 & 1.04 & 0.079 & 0.073 & 0.059 & 0.370 & 0.036 & 0.036 \\
\hline 42 & 0.011 & 2 & 0.85 & 0.038 & 0.26 & 0.52 & 0.068 & 0.071 & 0.103 & 0.780 & 0.027 & - \\
\hline 43 & 0.005 & 2 & 0.85 & 0.038 & 0.26 & 0.52 & 0.072 & 0.040 & 0.070 & 0.310 & 0.028 & - \\
\hline 44 & 0.005 & 1 & 0.85 & 0.038 & - & 0.52 & 0.074 & 0.042 & 0.079 & 0.300 & 0.028 & - \\
\hline 45 & 0.005 & 1 & 0.85 & 0.038 & - & 0.52 & 0.074 & 0.036 & 0.091 & 0.360 & 0.022 & - \\
\hline 46 & 0.011 & 1 & 0.85 & 0.038 & - & 0.52 & 0.074 & 0.072 & 0.142 & 0.900 & 0.033 & - \\
\hline 47 & 0.011 & 1 & 0.85 & 0.038 & - & 0.52 & 0.074 & 0.063 & 0.124 & 0.960 & 0.023 & - \\
\hline 48 & 0.008 & 3 & 0.85 & 0.038 & 0.26 & 0.52 & 0.076 & 0.058 & 0.102 & 0.670 & 0.029 & - \\
\hline 49 & 0.011 & 2 & 0.85 & 0.038 & 0.26 & 1.04 & 0.073 & 0.071 & 0.097 & 0.920 & 0.050 & - \\
\hline 50 & 0.008 & 2 & 0.85 & 0.038 & 0.26 & 1.04 & 0.074 & 0.060 & 0.067 & 0.580 & 0.030 & - \\
\hline 51 & 0.005 & 2 & 0.85 & 0.038 & 0.26 & 1.04 & 0.074 & 0.040 & 0.053 & 0.480 & 0.027 & - \\
\hline 52 & 0.005 & 1 & 0.85 & 0.038 & - & 1.04 & 0.075 & 0.042 & 0.051 & 0.380 & 0.028 & - \\
\hline 53 & 0.011 & 1 & 0.85 & 0.038 & - & 1.04 & 0.075 & 0.072 & 0.093 & 0.670 & 0.036 & - \\
\hline
\end{tabular}

For all the tests, clear water conditions were maintained and the flow intensity $\left(U / U_{c}\right)$ varied between 0.72 to 0.99 , where $U$ and $U_{c}$ are the mean and critical flow velocity, respectively. $U_{c}$ was calculated according to the methodology proposed by [29,30]. Before each test, the channel bed was levelled and made horizontal. During the test, discharge was kept constant, and the tailwater was controlled by means of a tailgate located at the downstream end of the channel. Tests were continued until the onset of equilibrium scour conditions, which took approximately $6 \mathrm{~h}$. In order to ensure the equilibrium condition of the scour morphology, some longer tests of a $12 \mathrm{~h}$ duration were conducted, and the difference between bed scour values at 6 and $12 \mathrm{~h}$ were found to be negligible (around $1 \mathrm{~mm})$. At the end of the test, the discharge was stopped, and water was slowly drained from the channel so as not to disturb the deformed bed.

Extensive measurements of the water depth and significant points of scour were taken with a point gauge having an accuracy of $0.1 \mathrm{~mm}$. In addition, the entire test section was surveyed using a "Leica Geosystems BLK 360" laser scanner, and a detailed point cloud of the bed morphology was recorded. Subsequent data processing and analysis using Cyclone software allowed for the development of high precision scour maps $( \pm 1 \mathrm{~mm})$ of the entire stilling basin. The accuracy of the laser scanner was further validated with readings from the point gauge, and the difference was less than $1 \mathrm{~mm}$. 


\section{Results and Discussion}

\subsection{Dimensional Analysis}

Dimensional analysis was performed in order to identify the main parameters governing the scour process due to wood bundles inserted in straight and curved channels First, the diffusion length parameter $\left(z_{m}+h_{t w}\right)$ was defined according to [5,11,21]; then, $\left(z_{m}\right.$ $\left.+h_{t w}\right)$ was expressed as a function of the following parameters:

$$
\left(z_{m}+h_{t w}\right)=f\left(B, Q, h_{s t}, g, l_{s t}, \Delta \rho, \rho, n, b, s, d_{50}, R, \alpha\right),
$$

Non-dimensional parameters were derived by applying the theorem of Buckingham and Incomplete Self-Similarity [31], which have been used to develop empirical equations capable of predicting morphological features of the scour and dune formations. By assuming $Q, h_{s t}$ and $\rho$ are repeating variables, the resulting 11 non-dimensional groups can be written as follows:

$$
\frac{\left(z_{m}+h_{t w}\right)}{h_{s t}}=f\left(\frac{B}{h_{s t}}, \frac{g h_{s t}^{5}}{Q^{2}}, \frac{l_{s t}}{h_{s t}}, \frac{\Delta \rho}{\rho}, n, \frac{b}{h_{s t}}, \frac{s}{h_{s t}}, \frac{d_{50}}{h_{s t}}, \frac{R}{h_{s t}}, \alpha\right),
$$

Moreover, by rearranging some of the non-dimensional groups in Equation (2), we obtain the following functional relationship:

$$
\frac{\left(z_{m}+h_{t w}\right)}{h_{s t}}=f\left(\frac{B}{h_{s t}}, \mathrm{~F}_{d e q}, \frac{l_{s t}}{B}, \frac{\Delta \rho}{\rho}, n, \frac{s}{B}, \frac{d_{50}}{B}, \frac{B-b}{R}, \alpha\right) \text {, }
$$

Here, $\mathrm{F}_{d e q}$ is defined as the densimetric Froude number, characterized by the following expression:

$$
\mathrm{F}_{\text {deq }}=\frac{Q}{B h_{s t} \sqrt{g d_{50} \frac{\Delta \rho}{\rho}}},
$$

The densimetric Froude number accounts for the effects of discharge, bed sediment characteristics and structure geometry (but not for the asymmetric distribution of flow velocity). The same parameter was used by [21] to analyse the scour phenomena due to chevrons inserted in straight and curved channels, and a similar one was adopted by [6] to investigate scour phenomena due to various hydraulic structures.

\subsection{Maximum Scour Depth and Length}

The global maximum scour depth is defined as $z_{m}=\max \left(z_{m-1}, z_{m-2}, z_{m-3}\right)$ for wood bundles inserted in straight channels and in the outer bank of curved channels and as $z_{m}=\max \left(z_{m-1}, z_{m-2}, z_{m-3}, z_{m b}\right)$ for wood bundles inserted in the inner bank of curved channels. Within the tested ranges of parameters, $z_{m}$ usually occurred upstream of the first wood bundle in the case of series arrangements. In this study, the ratios $\Delta \rho / \rho=1.467, d_{50} / B$ $=0.002$ and $l_{s t} / B=0.32$ were kept constant, and the parameters $B / h_{s t}$ and $s / B$ did not affect the maximum scour depth in the investigated range (i.e., $6.3 \leq B / h_{s t} \leq 7.4$ and $0.26 \leq s / B$ $\leq 0.52)$. Furthermore, the effects of $n$ and $\alpha$ on $\left(z_{m}+h_{t w}\right)$ are negligible for the tested ranges (i.e., $1 \leq n \leq 3$ and $0.52 \leq \alpha \leq 1.04$ ). Based on these considerations, Equation (3) can be rewritten as

$$
\frac{\left(z_{m}+h_{t w}\right)}{h_{s t}}=f\left(\mathrm{~F}_{\text {deq }}, \frac{B-b}{R}\right),
$$

For the tested conditions, $\left(z_{m}+h_{t w}\right) / h_{s t}$ was plotted against $\mathrm{F}_{d e q}$ (Figure 4 ), along with the plot of Equation (6), which predicts experimental data pertaining to structures located in straight channels (Figure 4a) (and in the inner bank of a curved channel, as shown in Figure $4 \mathrm{~b})$. Note that Equation (6) is valid for $1<\mathrm{F}_{d e q}<3$ and $0.85<\left(z_{m}+h_{t w}\right) / h_{s t}<2.9$.

$$
\left.\frac{\left(z_{m}+h_{t w}\right)}{h_{s t}}=0.854 \cdot \exp \left(0.283 \cdot \mathrm{F}_{d e q}\right)\right),
$$



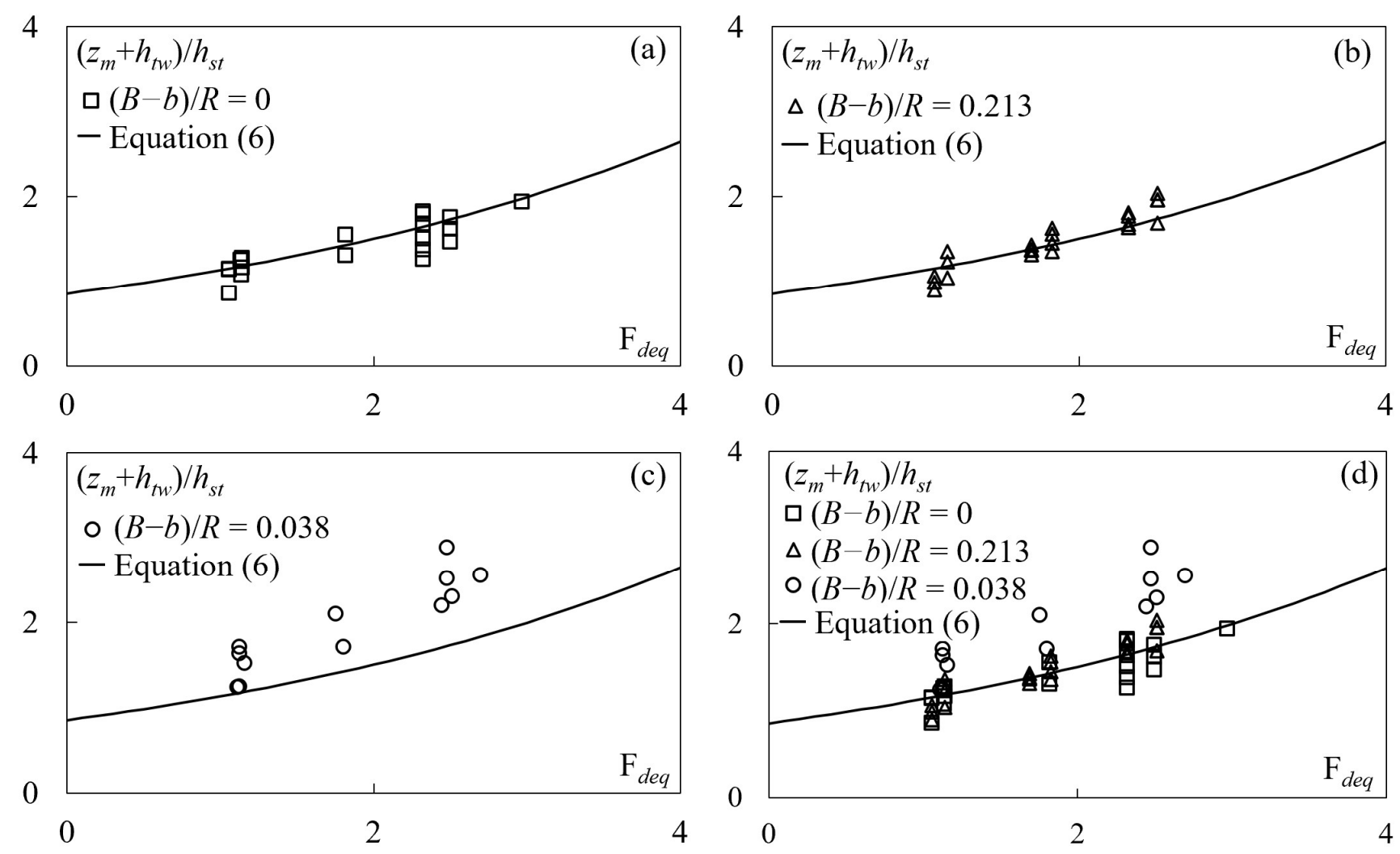

Figure 4. $\left(z_{m}+h_{t w}\right) / h_{s t}$ vs. $\mathrm{F}_{d e q}$ for wood bundles inserted in (a) a straight channel, i.e., $(B-b) / R=0$; $(\mathbf{b})$ the inner bank of a curved channel, i.e., $(B-b) / R=0.213$; (c) the outer bank of a curved channel, i.e., $(B-b) / R=0.038$. Figure (d) summarizes all the channel types.

However, the scour due to wood bundles inserted in the outer bank of a curved channel is underestimated by Equation (6) (Figure 4c,d). This occurs because velocities in proximity toof the outer bank are greater with respect to the inner bank, thus causing a deeper scour. To account for this phenomenon, $\mathrm{F}_{\text {deq }}$ was replaced by a modified densimentric Froude number $\mathrm{F}^{*}$ deq in Equation (6):

$$
\frac{\left(z_{m}+h_{t w}\right)}{h_{s t}}=0.854 \cdot \exp \left(0.283 \cdot \mathrm{F}_{d e q}^{*}\right)
$$

The modified densimetric Froude number accounts for the radius of curvature $R$ and for the distance of the centre of mass of the wood bundle from the inner bank $b$, i.e., for the asymmetric distribution of flow velocity, and it was found to be equal to

$$
\mathrm{F}_{\text {deq }}^{*}=\mathrm{F}_{\text {deq }} \cdot\left[-86 \cdot\left(1-\frac{B-b}{R}\right)^{2}+154 \cdot\left(1-\frac{B-b}{R}\right)-67\right]
$$

By substituting Equation (8) in Equation (7), the non-dimensional parameter $\left(z_{m}+\right.$ $\left.h_{t w}\right) / h_{s t}$ can be satisfactorily predicted for all the tested configurations, as shown in Figure $5\left(\mathrm{R}^{2}=0.80\right)$. Thus, Equations (7) and (8) are valid within the following ranges: $0.99 \leq \mathrm{F}^{*}$ deq $\leq 4.2 ; 6.3 \leq B / h_{s t} \leq 7.4 ; l_{s t} / B=0.32 ; 0 \leq(B-b) / R \leq 0.213 ; 1 \leq n \leq 3 ; 0.52 \mathrm{rad} \leq \alpha \leq 1.04$ rad; $0.26 \leq s / B \leq 0.52$. It is worth noting that $\mathrm{F}_{\text {deq }}=\mathrm{F}_{\text {deq }}$ for straight channels, i.e., for $R$ tending to infinity. Thus, for straight channels, Equation (7) becomes analytically identical to Equation (6). 

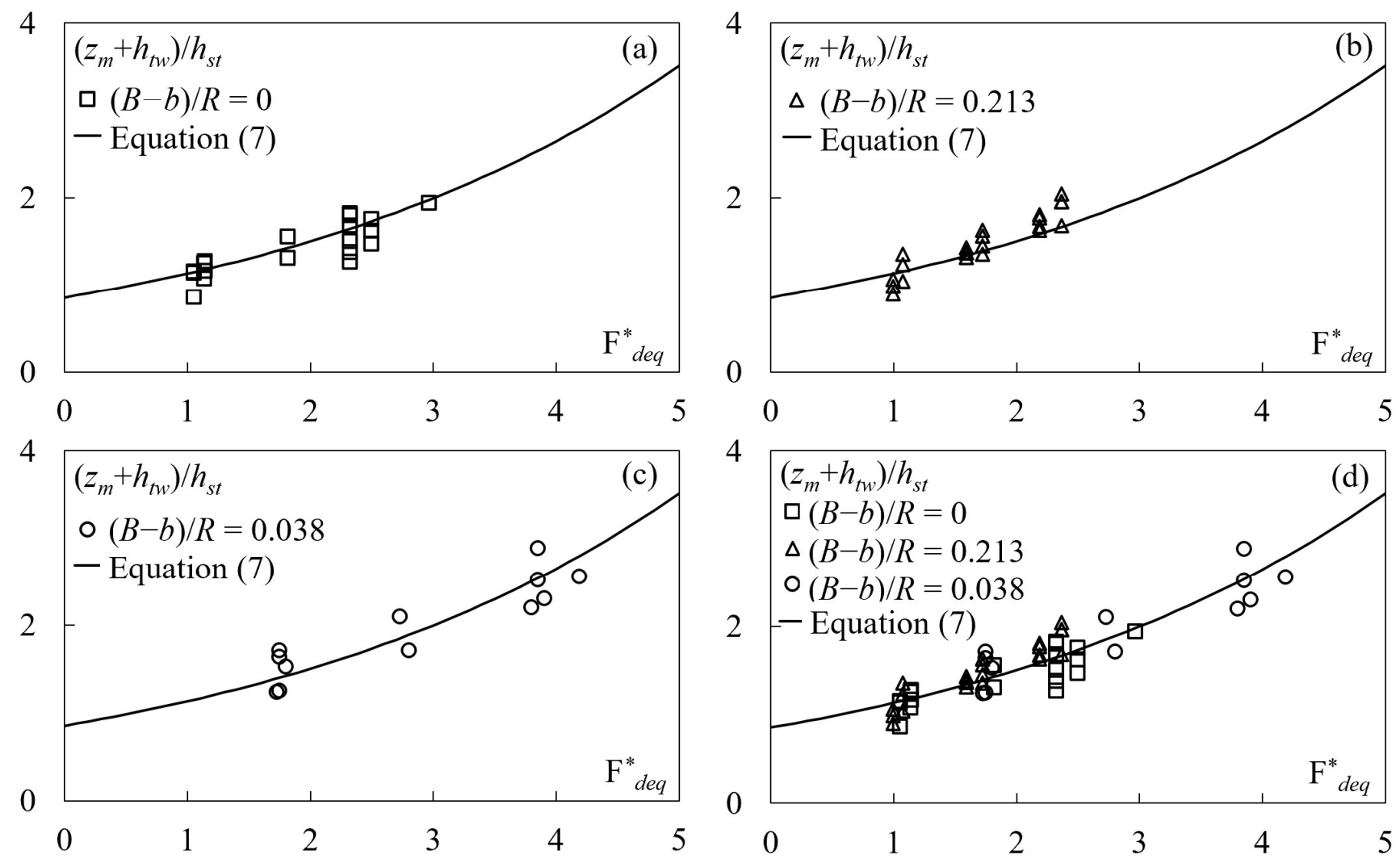

Figure 5. $\left(z_{m}+h_{t w}\right) / h_{s t}$ vs. $\mathrm{F}_{\text {deq }}^{*}$ for wood bundles inserted in (a) a straight channel, i.e., $(B-b) / R=0$; (b) the inner bank of a curved channel, i.e., $(B-b) / R=0.213$; (c) the outer bank of a curved channel, i.e., $(B-b) / R=0.038$. Figure (d) summarizes all the channel types.

The scour length due to wood bundles inserted in straight and curved channels was investigated following a similar approach. Maximum scour length $\left(l_{m}\right)=\max \left(l_{m-1}, l_{m-2}\right.$, $\left.l_{m-3}\right)$ usually occurs in the vicinity of the first structure in a series arrangement. Within the range of tested parameters, $\left(l_{m}+h_{t w}\right) / h_{s t}$ was plotted against $\mathrm{F}^{*}$ deq in Figure 6, and the following expression was derived $\left(\mathrm{R}^{2}=0.70\right)$ :

$$
\frac{\left(l_{m}+h_{t w}\right)}{h_{s t}}=2.777 \cdot \exp \left(0.346 \cdot F_{d e q}^{*}\right)
$$

The relationship is valid within the following ranges: $0.99 \leq \mathrm{F}^{*}$ deq $\leq 4.2 ; 6.3 \leq B / h_{s t} \leq$ $7.4 ; l_{s t} / B=0.32 ; 0 \leq(B-b) / R \leq 0.213 ; 1 \leq n \leq 3 ; 0.52 \mathrm{rad} \leq \alpha \leq 1.04 \mathrm{rad} ; 0.26 \leq s / B \leq 0.52$.

Finally, the depth of the scour occurring near the outer bank $z_{m b}$ was investigated in the case of wood bundles inserted along the inner bank of a curved channel, i.e., $(B-b) / R=0.213$. Namely, $z_{m b}$ was investigated only in the above case because, for straight channels, i.e., $(B-b) / R=0$, the scour in proximity of the far bank does not pose a serious threat to bank safety. In addition, for wood bundles inserted in the outer bank of curved channels, i.e., $(B-b) / R=0.038, z_{m b}$ is accounted for by $z_{m-1}, z_{m-2}$ and $z_{m-3}$. Therefore, the parameter $\left(z_{m b}+h_{t w}\right) / h_{s t}$ was plotted against $\mathrm{F}_{\text {deq }}^{*}$ in Figure 7 , and the data trend was interpolated using Equation $(10)\left(\mathrm{R}^{2}=0.84\right)$ :

$$
\frac{\left(z_{m b}+h_{t w}\right)}{h_{s t}}=0.287 \cdot \exp \left(0.737 \cdot \mathrm{F}_{d e q}^{*}\right)
$$

The equation is valid within the following ranges: $0.99 \leq \mathrm{F}_{\text {deq }}^{*} \leq 2.4 ; 6.3 \leq B / h_{s t} \leq$ $6.9 ; l_{s t} / B=0.32 ;(B-b) / R=0.213 ; 1 \leq n \leq 3 ; 0.52 \mathrm{rad} \leq \alpha \leq 1.04 \mathrm{rad}, s / B=0.26$. 


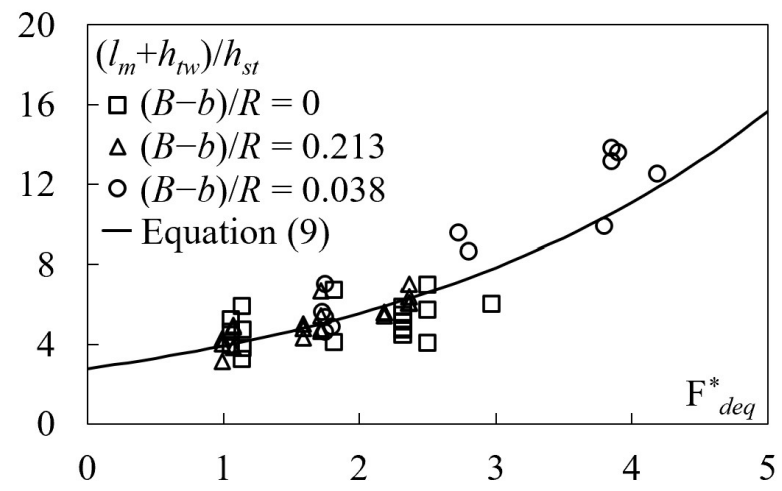

Figure 6. $\left(l_{m}+h_{t w}\right) / h_{s t}$ vs. $F_{d e q}^{*}$ for wood bundles inserted in a straight channel $((B-b) / R=0)$ and the inner $((B-b) / R=0.213)$ and outer $((B-b) / R=0.038)$ banks of a curved channel, along with the plot of Equation (9).

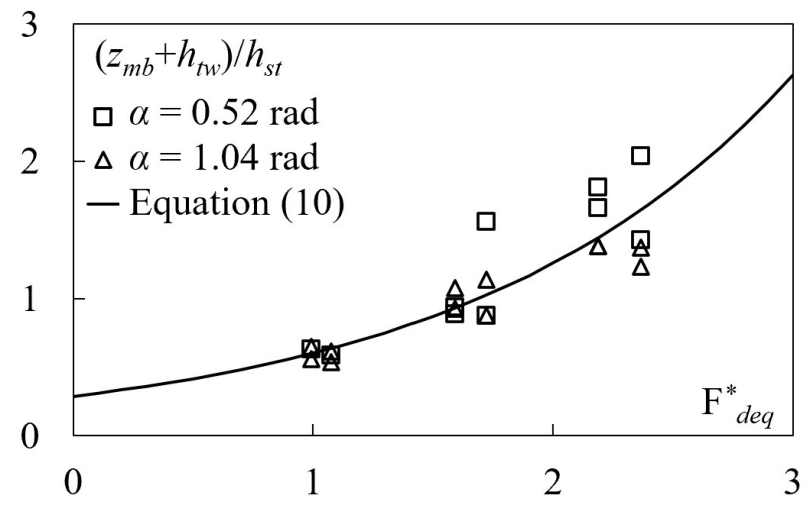

Figure 7. $\left(z_{m b}+h_{t w}\right) / h_{s t}$ vs. $\mathrm{F}_{\text {deq }}^{*}$ for wood bundles inserted in the inner $((B-b) / R=0.213)$ bank of curved channel for different values of $\alpha$, along with the plot of Equation (10).

\subsection{Maximum Dune Height}

The height of the dune $z_{M}=\max \left(z_{M-1}, z_{M-2}, z_{M-3}\right)$ is a significant scour feature, which should be quantified for design purposes. Based on the dimensional arguments illustrated above, the following predicting equation was derived for the non-dimensional maximum dune height and plotted in Figure $8\left(R^{2}=0.60\right)$.

$$
\frac{\left(z_{M}+h_{t w}\right)}{h_{s t}}=0.659+0.233 \cdot F_{d e q^{\prime}}^{*}
$$

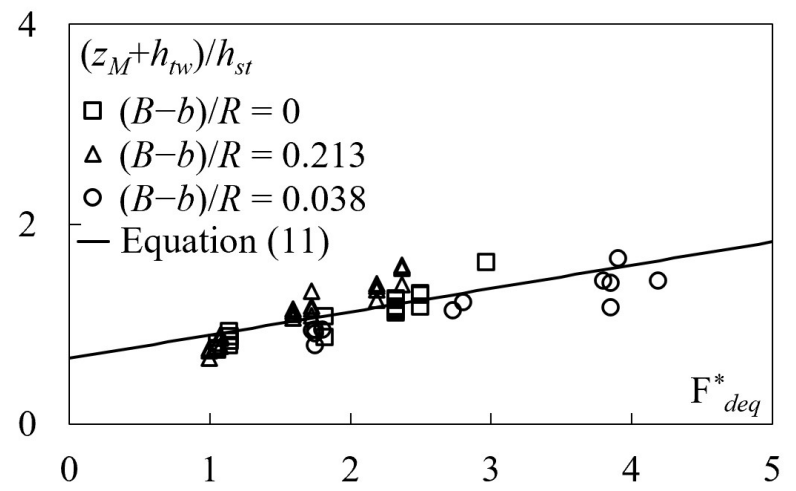

Figure 8. $\left(z_{m}+h_{t w}\right) / h_{s t}$ vs. $\mathrm{F}_{\text {deq }}^{*}$ for wood bundles inserted in a straight channel $((B-b) / R=0)$ and the inner $((B-b) / R=0.213)$ and outer $((B-b) / R=0.03)$ banks of curved channel, along with the plot of Equation (11). 
The equation is valid within the following ranges: $0.99 \leq \mathrm{F}_{\text {deq }}^{*} \leq 4.2 ; 6.3 \leq B / h_{s t} \leq 7.4$; $l_{s t} / B=0.32 ; 0 \leq(B-b) / R \leq 0.213 ; 1 \leq n \leq 3 ; 0.52 \mathrm{rad} \leq \alpha \leq 1.04 \mathrm{rad} ; 0.26 \leq s / B \leq 0.52$.

\subsection{Scour Geometry Features}

The equilibrium scour morphology types due to wood bundles in straight and curved channels are classified and their fields of existence are established to aid in the design of such structures. Various occurring scour morphologies for wood bundle series with two structures $(n=2)$ are shown in Figure 9. The corresponding scour morphologies for $n=1$ or $n=3$ are similar. In straight channels for $(B-b) / R=0$, two different morphology types were observed, i.e., Type $A_{s}$ (Figure $9 \mathrm{a}$ ) and Type $B_{s}$ (Figure $9 \mathrm{~b}$ ). In Type $A_{s}$, separate scour zones were formed in the vicinity of the wood bundle structure, which in turn remained confined by an elongated dune that extended downstream from the structure arrangement. Conversely, in Type $B_{s}$ the scour zone in the vicinity of each structure became more pronounced and extended in nature. An additional elongated scour zone was formed along the far bank of the channel. The dune region became more enhanced and extended further downstream compared to that in Type $A_{s}$.

Type $A_{s}$

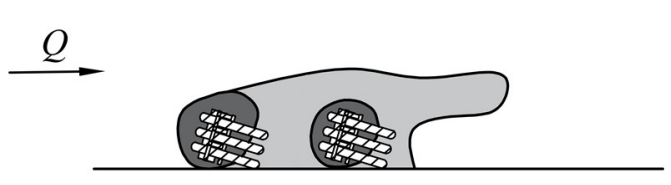

Type $A_{i}$

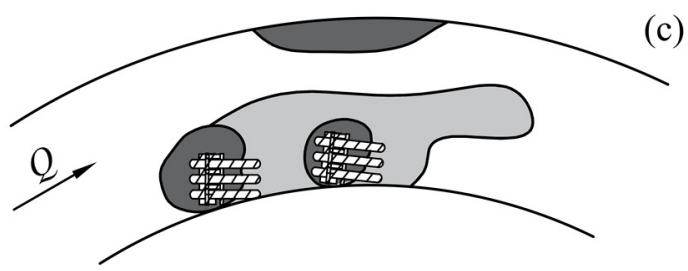

Type $A_{o}$

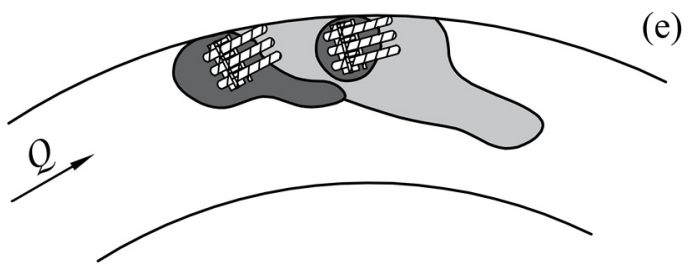

wood bundle

(a)

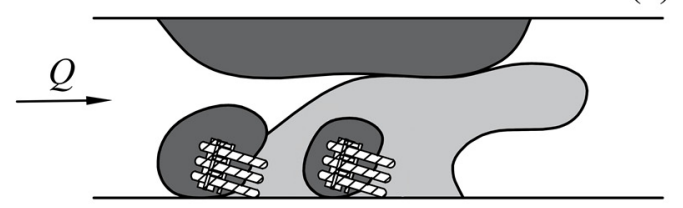

Type $B_{i}$

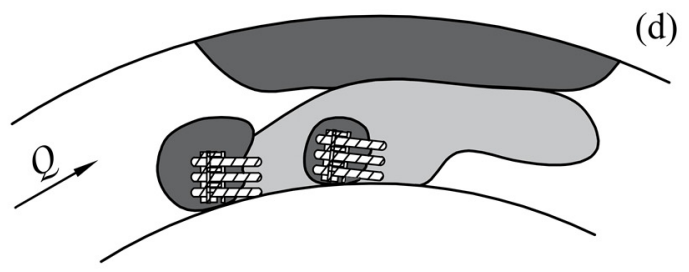

Type $B_{o}$

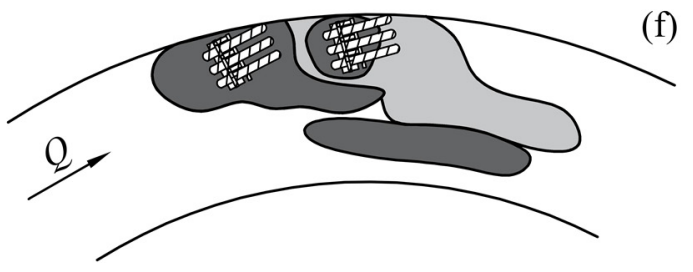

dune

Figure 9. Scour morphology types for wood bundles in straight and curved channels: Types (a) $A_{s}$ and (b) $B_{S}$ for the straight channel, i.e., $(B-b) / R=0$; Types (c) $A_{i}$ and (d) $B_{i}$ for the curved channel inner bank position, i.e., $(B-b) / R=0.213$; Types $(\mathbf{e})$ $A_{o}$ and (f) $B_{o}$ for the curved channel outer bank position, i.e., $(B-b) / R=0.038$.

Following this, the analysis was extended to curved channels in the case of structure position along the inner bank, i.e., $(B-b) / R=0.213$. Figure $9 \mathrm{c}$ and $\mathrm{d}$ show Types $A_{i}$ and $B_{i}$ applicable for this case, corresponding to Types $A_{s}$ and $B_{S}$ in straight channels. Type $A_{i}$ exhibited strong similarity with that of straight channels, resulting in scour formations near the individual wood bundle structures, along with a dune. In addition, for curved channels, the flow entering the stilling basin was asymmetric and concentrated towards the outer bank due to the action of centrifugal acceleration, resulting in a shallow scour 
region in the outer bank vicinity in Type $A_{i}$. Conversely, for Type $B_{i}$, this effect was more pronounced, and increased shear stresses occurring near the outer bank caused a deep and elongated scour region (Figure 9d). The dune region also increased in dimension and extended downstream into the channel running parallel to the scour along the outer bank.

Figure $9 \mathrm{e}, \mathrm{f}$ show the morphology Types $A_{o}$ and $B_{0}$ in the case of structure position along the outer bank in curved channels, i.e., $(B-b) / R=0.038$. In general, the scour region in the vicinity of the first structure in the series for this position was more enhanced and elongated in nature compared to that in the previous two structure positions due to the increased scour potential caused by the channel curvature. Type $A_{o}$ was characterized by scour formations in the vicinity of the wood bundles, followed by a dune extending downstream into the channel. Both the dune and scour regions became more elongated and deeper in the case of Type $B_{0}$. However, on comparing Type $B_{o}$ with Type $B_{i}$, it can be said that in the case of the former, the increased flow gradient was partially diverted toward the channel axis, which led to the formation of an elongated scour in the central part of the channel. This could prove to be beneficial in terms of offering better bank protection and creating eco-friendly scour pools that could serve as fish nurseries and/or promote the growth of aquatic flora and fauna.

The fields of existence of the equilibrium scour morphology types described above were established based on the parameters $h_{s t} / h_{t w}, R / h_{t w}$ and $\mathrm{F}_{d e q}^{*}$, following the methodology proposed by $[20,24]$. Therefore, in Figure 10a, $h_{s t} / h_{t w}$ values are plotted against corresponding $\mathrm{F}_{\text {deq }}^{*}$ for $(B-b) / R=0$. Keeping $\mathrm{F}_{\text {deq }}^{*}$ constant by lowering the tailwater level, a transition from Type $A_{s}$ to $B_{s}$ occurred. This could be explained by a corresponding decrease in the jet diffusion length, which caused a proportional increase in the shear stress and scouring capacity, resulting in Type $B_{S}$ being characterised by more pronounced scour holes in the structure vicinity and far bank of the channel [12,13]. In addition, when other parameters were constant, higher Froude numbers could be associated with higher velocity, which facilitates scour formation and results in scour morphology Type $B_{s}$ (Figure $9 \mathrm{~b}$ ). Figure $10 \mathrm{~b}, \mathrm{c}$ show plots of $R / h_{t w}$ vs. $\mathrm{F}_{d e q}^{*}$ in the case of the inner bank position, i.e., $(B-b) / R=0.213$ and outer bank position, i.e., $(B-b) / R=0.038$, respectively. However, the fields of existence of the different scour morphologies in these cases showed the same characteristics as those of straight channels. For both inner and outer bank positions, a transition from Type $A_{i}\left(A_{o}\right)$ to Type $B_{i}\left(B_{o}\right)$ could be obtained by a decrease in $h_{t w}$ or an increase in $\mathrm{F}_{\text {deq }}^{*}$ values for otherwise constant hydraulic and geometric conditions. Moreover, Type $A_{i}$ and $A_{o}$ did not occur for Froude numbers greater than two in the curved channels because of the effect of channel curvature, which facilitated the formation of extended scour zones in the outer bank vicinity, resulting in Type $B_{i}$ or $B o$ (Figure $9 \mathrm{~d}, \mathrm{f}$ ).

Figure 11 shows scour maps corresponding to tests 4 and 3 , with identical discharge, structure position and geometry $\left(Q=0.008 \mathrm{~m}^{3} / \mathrm{s}, n=1\right.$ and $\left.(B-b) / R=0\right)$ but with different tailwater level and scour morphology, such as (a) $h_{t w}=0.06 \mathrm{~m}$ and Type $A_{s}$ and (b) $h_{t w}=0.042 \mathrm{~m}$ and Type $B_{s}$. In fact, by decreasing the tailwater level we obtained a transition from Type $A_{s}$ to $B_{s}$, which corroborates the findings reported in Figure 10a. In Figure 12, two scour maps are presented, corresponding to tests 38 and 49 , with similar hydraulic and structure characteristics $\left(Q=0.011 \mathrm{~m}^{3} / \mathrm{s}, n=2, \alpha=1.04 \mathrm{rad}\right.$ and $\left.h_{t w}=0.07 \mathrm{~m}\right)$ but with (a) inner bank position, i.e., $(B-b) / R=0.213$ and Type $B_{i}$ and (b) outer bank position, i.e., $(B-b) / R=0.038$ and Type $B_{0}$. On comparison of the two figures, it can be concluded that the scour in the vicinity of wood bundles becomes more pronounced in case of Type $B_{o}$ compared to that in $B_{i}$ due to the effect of the channel curvature. However, the wood bundles located at the outer bank are successful in partially directing the stream flow towards the centre of the channel, which results in an eco-friendly scour pool, as shown in Figure 9f. In general, in both straight and curved channels, the localised scour holes in the vicinity of the wood bundle structure can act as resting spots for fish, and the elongated dune region can be used as a spawning site. However, in case of Type $B_{i}$ and $B_{0}$, suitable countermeasures should be designed to ensure bank protection. The central scour pool formed in the case of Type $B_{o}$ can help to create and sustain bio-diversity in the channel. 

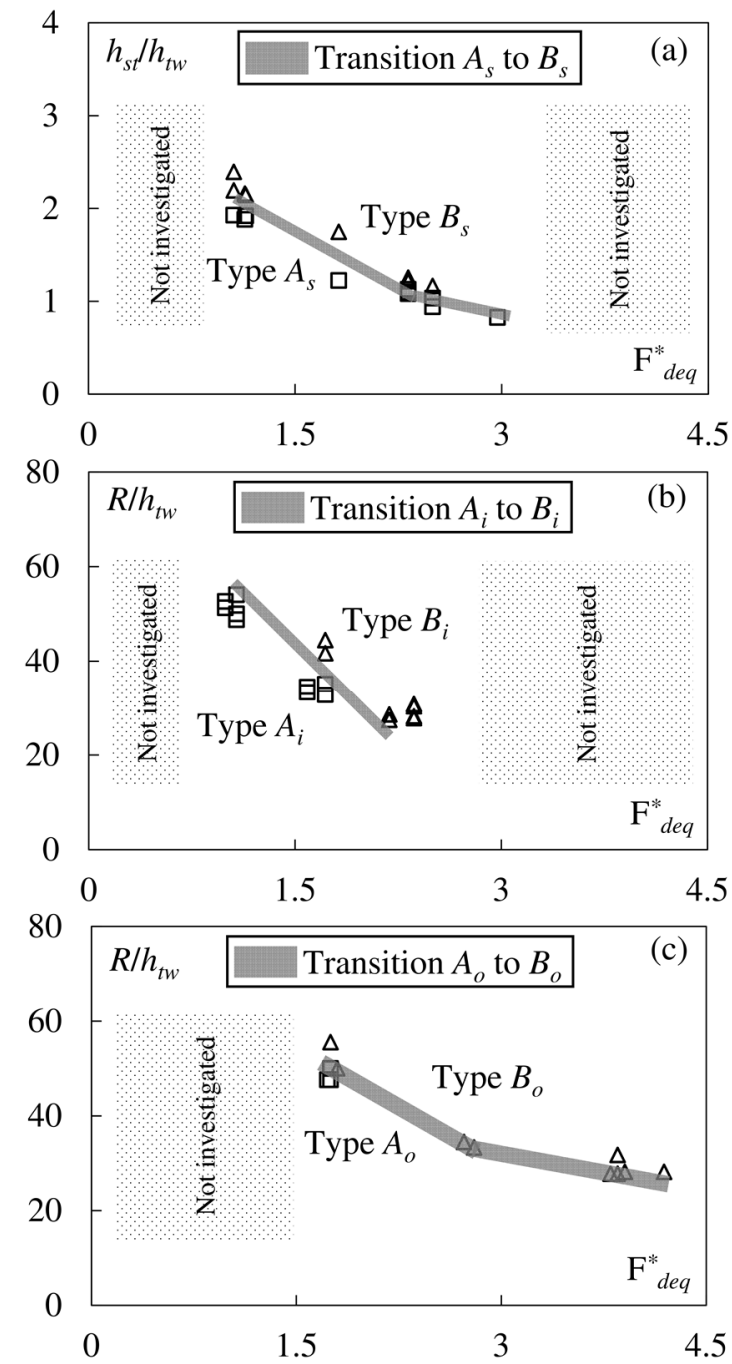

Figure 10. Fields of existence of scour morphology types for wood bundles corresponding to (a) the straight channel position, i.e., $(B-b) / R=0,(\mathbf{b})$ the inner bank position, i.e., $(B-b) / R=0.213$ and (c) the outer bank position, i.e., $(B-b) / R=0.038$.

(a)

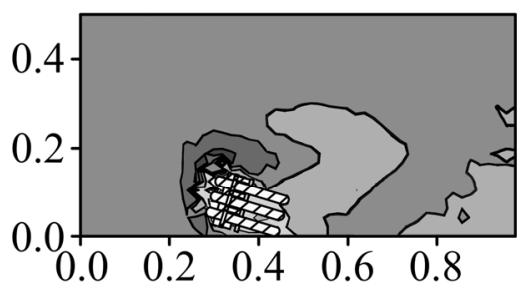

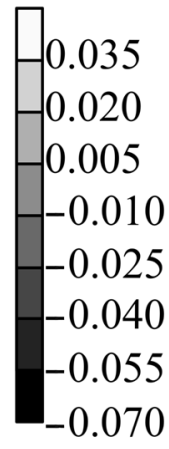

(b)
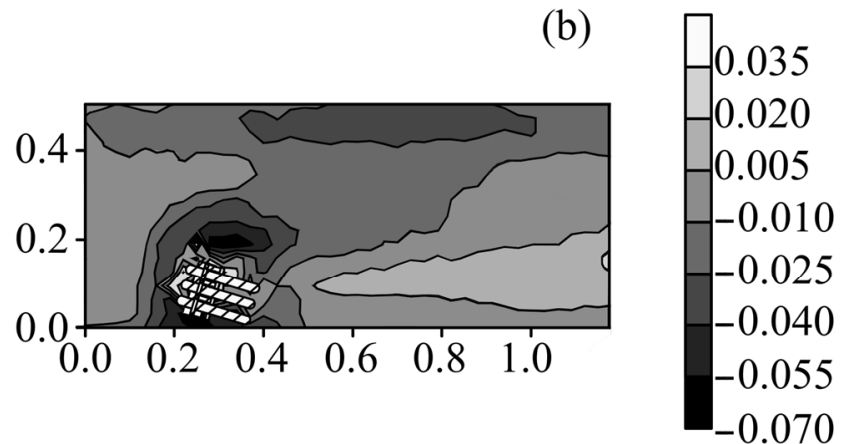

\section{7 wood bundle}

Figure 11. Scour maps for (a) test 4, having Type $A_{s}$, and (b) test 3 , having Type Bs. All dimensions are in metres, and the flow is from left to right. 
(a)

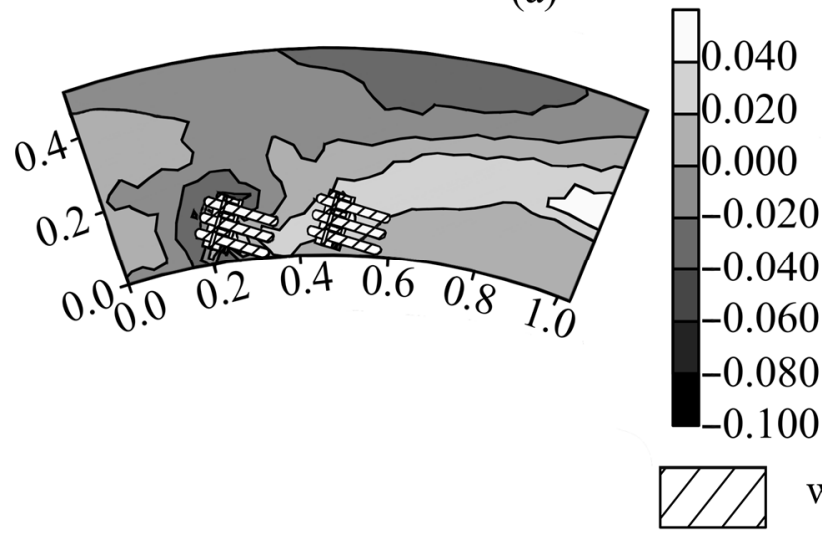

(b)

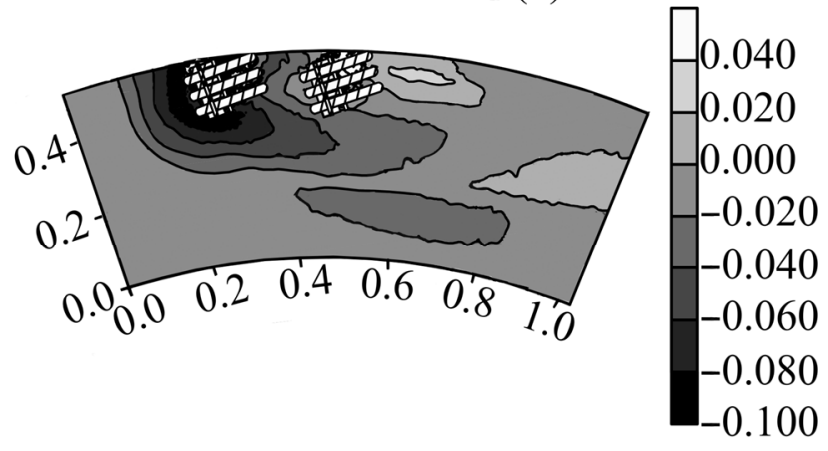

wood bundle

Figure 12. Scour maps for (a) test 38 , having Type $B_{i}$, and (b) test 49 , having Type $B o$. All dimensions are in metres and the flow is from left to right.

\section{Conclusions}

Isolated and series arrangements of wood bundle structures were tested in straight and curved channels under a variety of longitudinal and transversal structure positions and hydraulic conditions. Rigorous dimensional analysis was carried out to deduce key parameters governing the scour phenomena, including the modified densimetric Froude number $\mathrm{F}_{\text {deq }}^{*}$, accounting for both the effects of structure transversal position and channel curvature on the scour process. Empirical equations were developed to predict the main features of the scour and dune region, including maximum scour depth and length as well as the maximum dune height, and had good accuracy. For every structure position, i.e., straight, inner channel bank and outer channel bank, two different types of scour morphology were classified, and their fields of existence were quantified based on $\mathrm{F}^{*}$ deq and $h_{s t} / h_{t w}$ or $R / h_{t w}$. By decreasing the tailwater level or by increasing the Froude number, a transition from Types $A_{S}, A_{i}, A_{o}$ to the corresponding Types $B_{S}, B_{i}, B_{o}$ could be obtained. In all cases, prominent scour pot holes occurred, particularly in the vicinity of the first structure in the series, which could be used by fish as shelter. Elongated dunes were also formed, which could be used for spawning purposes. On comparison of Types $B_{i}$ and $B_{0}$ in the cases of inner bank and outer bank positions, respectively, in curved channels, we see that, in case of the latter, the structure was effective in partially redirecting the asymmetric flow towards the centre of the channel. This led to the generation of an elongated scour region along the channel axis, which could promote biodiversity. In summary, this paper presents novel experimental results that can facilitate the design of large wood debris bundles as grade-control and eco-restoration structures in straight and curved rivers.

Author Contributions: Conceptualization, M.P., D.R. and S.P.; methodology, M.P., D.R. and S.P.; validation, M.P., D.R. and S.P.; formal analysis, M.P., D.R. and S.P.; investigation, M.P., D.R. and S.P.; data curation, M.P., D.R. and S.P.; writing-original draft preparation, M.P., D.R. and S.P.; writingreview and editing, M.P., D.R. and S.P.; supervision, M.P. All authors have read and agreed to the published version of the manuscript.

Funding: This research received no external funding.

Institutional Review Board Statement: Not applicable.

Informed Consent Statement: Not applicable.

Data Availability Statement: All data used during the study appear in Table 1.

Acknowledgments: The authors would like to thank the technicians of the hydraulics laboratory of the University of Pisa, Nicola Bruni, Antonio Cecchi, Alessandro Michelotti, and Vincenzo Pennabea, for their help in building the experimental apparatus.

Conflicts of Interest: The authors declare no conflict of interest. 


\section{References}

1. Gillilan, S.; Boyd, K.; Hoitsma, T.; Kauffman, M. Challenges in developing and implementing ecological standards for geomorphic river restoration projects: A practitioner's response to Palmer et al. (2005). J. Appl. Ecol. 2005, 42, 223-227. [CrossRef]

2. Rosgen, D.L. The cross-vane, W-weir and J-hook vane structures: Their description, design and application for stream stabilization and river restoration. In Proceedings of Wetland Engineering and River Restoration Conf. (CD-ROM); American Society of Civil Engineers: Reston, VA, USA, 2001.

3. Schoklitsch, A. Kolkbildung unter Uberfallstrahlen [Scour formation under jets]. Wasserwirstchaft 1932, 25, 341-343.

4. Veronese, A. Erosioni di fondo a valle di uno scarico [Scour downstream of a waterfall]. Ann. Lav. Pubbl. 1937, 75, 717-726.

5. Bormann, N.E.; Julien, P.Y. Scour downstream of grade-control structures. J. Hydraul. Eng. 1991, 117, 579-594. [CrossRef]

6. D'Agostino, V.; Ferro, V. Scour on alluvial bed downstream of grade-control structures. J. Hydraul. Eng. 2004, 130, 1-14. [CrossRef]

7. Dey, S.; Sarkar, A. Scour downstream of an apron due to submerged horizontal jets. J. Hydraul. Eng. 2006, 132, 246-257. [CrossRef]

8. Dey, S.; Sarkar, A. Characteristics of submerged jets in evolving scour hole downstream of an apron. J. Eng. Mech. 2008, 134, 927-936. [CrossRef]

9. Mason, P.J.; Arumugam, K. Free jet scour below dams and flip buckets. J. Hydraul. Eng. 1985, 111, 220-235. [CrossRef]

10. Breusers, H.N.C.; Raudkivi, A.J. Scouring: Hydraulic Structures Design Manual Series; Balkema: Leiden, The Netherlands, 1991.

11. Hoffmans, G.J.C.M. Jet scour in equilibrium phase. J. Hydraul. Eng. 1998, 124, 430-437. [CrossRef]

12. Bombardelli, F.A.; Palermo, M.; Pagliara, S. Temporal evolution of jet induced scour depth in cohesionless granular beds and the phenomenological theory of turbulence. Phys. Fluids 2018, 30,1-19. [CrossRef]

13. Palermo, M.; Pagliara, S.; Bombardelli, F.A. Theoretical approach for shear-stress estimation at 2D equilibrium scour holes in granular material due to subvertical plunging jets. J. Hydraul. Eng. 2020, 146, 1-12. [CrossRef]

14. Bhuiyan, F.; Hey, R.D.; Wormleaton, P.R. Hydraulic evaluation of W-weir for river restoration. J. Hydraul. Eng. 2007, 133, 596-609. [CrossRef]

15. Bhuiyan, F.; Hey, R.D.; Wormleaton, P.R. Bank-attached vanes for bank erosion control and restoration of river meanders. J. Hydraul. Eng. 2010, 136, 583-596. [CrossRef]

16. Scurlock, S.M.; Thornton, C.I.; Abt, S.R. Equilibrium scour downstream of three-dimensional grade-control structures. J. Hydraul. Eng. 2012, 138, 167-176. [CrossRef]

17. Pagliara, S.; Kurdistani, S.M.; Santucci, I. Scour downstream of J-Hook vanes in straight horizontal channels. Acta Geophys. 2013, 61, 1211-1228. [CrossRef]

18. Pagliara, S.; Kurdistani, S.M. Clear water scour at J-Hook Vanes in channel bends for stream restorations. Ecol. Eng. 2015, 83, 386-393. [CrossRef]

19. Pagliara, S.; Palermo, M.; Roy, D. Experimental investigation of erosion processes downstream of block ramps in mild curved channels. Environ. Fluid. Mech. 2020, 20, 339-356. [CrossRef]

20. Palermo, M.; Roy, D.; Pagliara, S. Morphological characteristics of eco-friendly protected basins downstream of block ramps in river bends. Geomorphology 2021, 377, 107587. [CrossRef]

21. Roy, D.; Pagliara, S.; Palermo, M. Experimental Analysis of Scour Features at Chevrons in Straight Channel. Water 2021, $13,971$. [CrossRef]

22. Pagliara, S.; Hassanabadi, L.S.; Kurdistani, S.M. Log-vane scour in clear water condition. River. Res. Appl. 2014, 31 , 1176-1182. [CrossRef]

23. Pagliara, S.; Hassanabadi, L.; Kurdistani, S.M. Clear water scour downstream of log deflectors in horizontal channels. J. Irrig. Drain. Eng. 2015, 141, 1-8. [CrossRef]

24. Pagliara, S.; Palermo, M.; Roy, D. Scour around double-winged log frames under clear water condition. J. Irrig. Drain. Eng. 2020, 146, 1-11. [CrossRef]

25. Fischenich, J.C.; Morrow, J.V., Jr. Streambank Habitat Enhancement with Large Woody Debris; Army Engineer Waterways Experiment Station Vicksburg MS Engineer Research and Development Center (ERDC TN-EMRRP-SR-13): Vicksburg, MI, USA, 2000.

26. Gippel, C.J. Environmental hydraulics of large woody debris in streams and rivers. J. Environ. Eng. 1995, 121, 388-395. [CrossRef]

27. Shields, F.D., Jr.; Gippel, C.J. Prediction of effects of woody debris removal on flow resistance. J. Hydraul. Eng. 1995, 121, 341-354. [CrossRef]

28. Oliveto, G.; Hager, W.H. Further results to time-dependent local scour at bridge elements. J. Hydraul. Eng. 2005, 131, 97-105. [CrossRef]

29. Neill, C.R. Note on initial movement of coarse uniform bed-material. J. Hydraul. Res. 1968, 6, 173-176. [CrossRef]

30. Palermo, M.; Pagliara, S.; Roy, D. Effect of debris accumulation on scour evolution at bridge pier in bank proximity. J. Hydrol. Hydromech. 2021, 1, 108-118. [CrossRef]

31. Barenblatt, G.I. Dimensional Analysis; Gordon and Breach Science: New York, NY, USA, 1987. 